\title{
Integrating Mind Mapping (MM) and Three-Step-Interview (TSI) in Enhancing Students' Writing Process in Foreign Language Setting
}

\author{
Flora \\ English Department \\ Faculty of Education \\ Lampung University \\ Indonesia
}

\begin{abstract}
There had been many studies conducted to investigate the benefits of Mind Mapping (MM) in the writing process and Three-Step-Interview (TSI) in the speaking process, this study set out to investigate the effectiveness of an integrated technique which was the combination of MM and TSI in teaching writing. This technique was intended to facilitate the students with individual and group brainstorming practice and to help create another teaching procedure which could effectively solve the students' writing problem, especially in generating and organizing ideas in the pre-writing process. The subject of this study was 29 students who took Intermediate Writing subject at English Department Faculty of Education, Lampung University-Indonesia. The pretest and posttest were administered before and after the treatment. The data was analyzed by means of the paired sample t-test. The result shows that the students' writing ability significantly improved subsequent to the treatment. It also reveals that the most significant improvements were those of the writing content and organization aspects. The results are discussed in relation to relevant previous research findings.
\end{abstract}

Keywords: Mind Mapping (MM) and Three Step Interview (TSI), Pre-writing, brainstorming ideas, Writing Ability, and Aspects of Writing

\section{Introduction}

In school, writing is a way of life because without some abilities to express yourself in writing, you do not pass the course (Brown, 2001). Further he declared that it is not only important in education but also to develop power in career. In line with this idea, Nunan (2003:87) stated that writing is the mental work of inventing ideas, thinking about how to express them, and organizing them into statements and paragraphs that will be clear to a reader. However, Heaton (1991) and Bryne (1993) stated that although learners have sufficient English vocabularies and grammar in the target language (English), writing is still considered as a difficult skill. Writing is not such a simple process because it needs to be integrated with grammar and vocabulary. Even professional writers need time or attempts to make good writing, for examples by editing or revising (Hogue et.al:1988).

In fact, the main problem lies in prewriting or brainstorming process, especially in generating and organizing the appropriate ideas related to writing topic (Richards and Renandya, 2002). In line with this, Brown (2001:335) elaborated that there are some aspects need to be considered in writing, they are; content, organization, vocabulary, grammar, and mechanical considerations (spelling and punctuation).

To have good final product of writing, one needs several writing processes, such as prewriting, drafting, revising, and editing (Graves, 1983) in Johnson (2008) . In relation to this, Bailey (2006) suggest the writer think first about the title or topic then elaborate any ideas related to the topic which is called drafting (Harmer, 2010) and this can be done using mind mapping Buzan (1989; 2012). To strengthen this idea, Harmer, J (2010), suggest teachers have some steps in teaching writing, such as; planning, drafting, editing, and final version. Harmer (2010) elaborates that another visual way of making preparation notes is often referred to as a spidergram or mind map. With respect to brainstorming, Bailey (2006) points out that it is best to begin the planning with the analysis of the topic and then to write down any seemingly relevant idea. The brainstorming process for pre-writing can also be done individually or in groups. For the individual brainstorming, the techniques mostly used are mind mapping and clustering. Generally speaking, the concepts of both techniques are similar. Those two are used to facilitate students with individual brainstorming practice through graphics in order for them to be able to organize their ideas. Harmer (2004:89) came up with the statement that another visual way of making preparation notes is often perceived as a spider gram or mind map. In this ideagenerating model, each student starts with a topic at the center and then generates a web of ideas out of the topic. Mind mapping is regarded as the easiest way of developing information in the human mind and of extracting it into written form. Simply put, it is a creative and effective way of mapping our ideas. 
In relation to Buzan's statement's $(1989 ; 2012)$ above, various studies on mind mapping have widely been used to improve learners' mastery of writing (Riswanto and Putra , 2012), (Triza, et.al ,2016), and Yunus and Chien, 2016). In Indonesia, this mind mapping have been widely used in teaching English writing. For example, Saputro AR, Basori, and Budiyanto, CW. ( 2017) declared that students of the eleventh graders of SMK SMK Negeri 2 Karanganyar, Semarang could increase their cognitive, affective, psychomotor, and liveliness; Ernidawati and Sutopo, D (2017) stated that of the students the the students of SMK Kesehatan Darussalam Semarang can help the students in writing skill for both students with high and low interest using mind mapping. Fadillah, R. (2019), found out that students of English Language Education, university in Malang, East Java enabled them to remember better about the ideas during the learning process using mind mapping. However, these pevious studies have not given indebth information to which of writing aspect it is most useful.

Considering the afore mentioned studies, it is reasonable to assume that student would probably avail themselves of mind mapping in terms of generating and organizing ideas for their writing. Yet, it was also the researchers' assumption that, if it was individual mind mapping, it would be less effective since they would organize ideas in a limited manner. Given the findings and deductions regarding brainstorming above, the researchers assumed group brainstorming to be more effective than individual brainstorming. Manktelow (2011:6) encourages group brainstorming as he believes it can be very effective in bringing forth an ultra-vital experience and plentifulcreativity of all the members of the groups. So, when one member gets stuck, another or other fellow members could help him/her out. In consideration of all this, the researchers conducted a study on the integration between mind mapping and group brainstorming.

In relation to group brainstorming, TSI is might be applicable since they may have other informations from others. Many reseachers hve been conducted dealing with TSI and mostly in the scope of Speaking activities. For example; Yuliasri, I. (2013) who stated that by using TPS, 8 teachers who participated on English teaching training program, they all admitted to apply this TSI in their real teaching since they found it effective aand fun; Candraloka. OR (2016) stated that it makes the learners active and speak naturally.; Fussalam, YE and and Renda Lestari, R.( 2018). After conducting classroopm action research to 15 students English Department of STKIP Muhammadiyah Muara Bungo (STKIP-MB) in learning process using TSI, their ability in speaking is better (Fussalam, YE and and Renda Lestari, R.,2018). In line with this, Aristy, I, Hadiansyah, R, and Apsari, Y (2019) also stated that the information gathered from the observation sheet indicated that the first-grade students at SMP Putra Juang, Cianjur, West Java were active during the learning process .

However, all the previous studies purely only implemented the concept of mind mapping, where student only organizes his own limited ideas and TSI in Speaking class activity. By modifying this mind mapping, that is, some concepts of TSI, it will provide the students another resource from his friends related to writing topic, and hopely it will minimaze the students' writing problem especially in prewriting process. TSI was used for group brainstorming which is considered more effective than individual and Mind mapping was used as the note, graphic organizer, and controller of the students' ideas for writing.

Briefly, the followings are the procedures of modified Mind Mapping :

1) The teacher explains the definition, generic structure, and language features of discussion text.

2) The procedures of modified mind mapping are also elaborated by the lecturer.

3) The lecturer gave some topics of discussion text.

4) A piece of paper for mind mapping is distributed for each student.

5) The students are divided in pairs and interview each other related to writing topics.

6) The students find new groups consist of five to share each other the ideas for writing. At the same time, they also start to generate and organize the ideas related to the writing topic in mind mapping paper individually.

7) Individually, they write a text based on the given topic.

Based on the background of the problem above, the questions to be focused on is :

What is the writing aspect which most significantly improves?

\section{Methodology}

Research Design

A quantitative study in the form of pre-experimental design is implemented. 


\section{Table .1: One-Group Pretest-Posttest Design}

\begin{tabular}{|l|l|l|}
\hline \multicolumn{1}{|c|}{ Pre-Test } & Independent & Post-Test \\
\hline $\mathrm{Y}_{1}$ & $\mathrm{X}$ & $\mathrm{Y}_{2}$ \\
\hline
\end{tabular}

(Source: Adapted from Ary, et.al, 2010:304)

\section{Participants}

To explore the effectiveness of modified Mind mapping in increasing students' ability in writing, 29 of students, majoring English, were involved as the participants of this study. They were selected since they have already taken Basic and Pre-intermediate writing. They have Writing class once a week in each semester. In the future, they are going to be English teachers at Junior and senior high school in Indonesia.

\section{Instruments}

Argumentative Essay Writing test which is meant to measure the effectiveness of integrated MM and TSI, was the instrument of this study. The topic was "What are the characters that a teacher should possess ?. Use reasons and examples to support your answer". It was given before the treatment (pre-test) and after the treatment (post-test).

Data Analysis

The data obtained from the pre-test and post-test were analyzed using the criteria proposed by Jacob's (1981). In scoring the students' work, it was done by two experienced English lecturers of Teacher training and education Faculty of Lampung University. Each rater gave the score based on Jacob's criteria (1981), namely : content (30\%), language use $(25 \%)$, organization (20\%), vocabulary $(20 \%)$, dan mechanics $(5 \%)$. Finally, the score of pre-test and post-test were compared using paired sample T-test.

\section{Results}

Table 1. The mean score of Pre-test

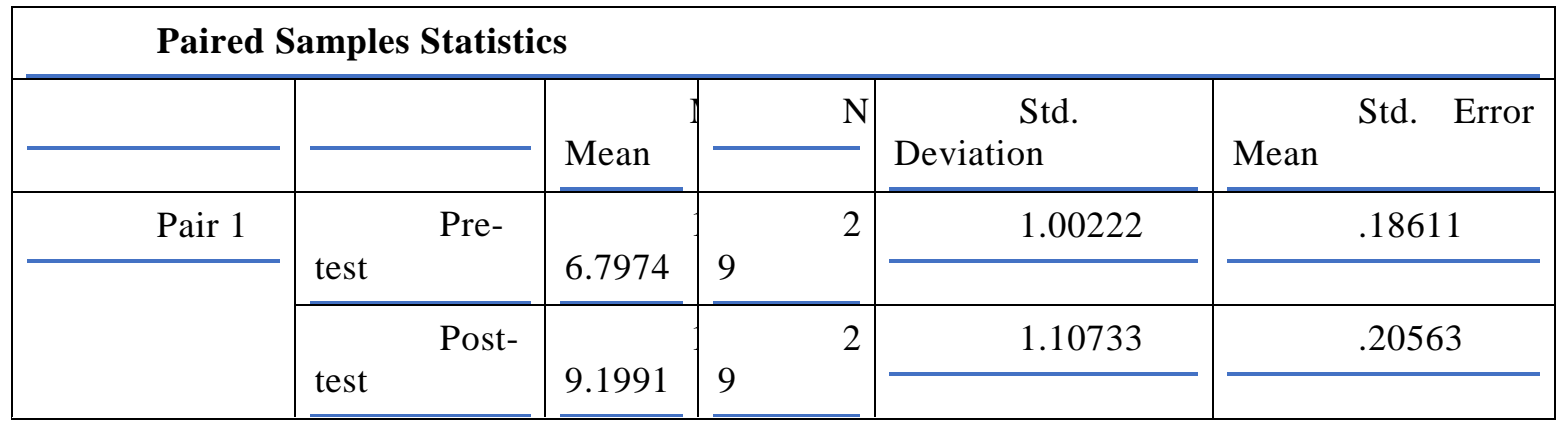

Paired Samples Correlations

\begin{tabular}{|lll|l|l|l|}
\hline \hline & & & $\begin{array}{l}\text { Correlati } \\
\text { on }\end{array}$ & Sig. \\
\hline Pair 1 & PRETEST \& & POST & 29 & .659 & .000 \\
\hline & & & & \\
\hline
\end{tabular}

Paired Samples Test

\begin{tabular}{|c|c|c|c|c|c|c|c|c|c|}
\hline & & \multicolumn{5}{|c|}{ Paired Differences } & \multirow[b]{3}{*}{$\mathrm{t}$} & \multirow[b]{3}{*}{ df } & \multirow{3}{*}{$\begin{array}{l}\text { Sig. (2- } \\
\text { tailed) }\end{array}$} \\
\hline & & \multirow[b]{2}{*}{ Mean } & \multirow{2}{*}{$\begin{array}{l}\text { Std. } \\
\text { Deviati } \\
\text { on }\end{array}$} & \multirow{2}{*}{$\begin{array}{l}\text { Std. } \\
\text { Error } \\
\text { Mean }\end{array}$} & \multicolumn{2}{|c|}{$\begin{array}{l}95 \% \\
\text { Confidence } \\
\text { Interval of the } \\
\text { Difference }\end{array}$} & & & \\
\hline & & & & & Lower & Upper & & & \\
\hline \multirow[t]{2}{*}{ Pair 1} & PRETEST & \multirow{2}{*}{$\begin{array}{l}2.4017 \\
2\end{array}$} & .87643 & \multirow{2}{*}{$\begin{array}{l}.1627 \\
5\end{array}$} & \multirow{2}{*}{$\begin{array}{l}- \\
2.7351 \\
0\end{array}$} & \multirow{2}{*}{$\begin{array}{l}- \\
2.0683 \\
5\end{array}$} & \multirow{2}{*}{$\begin{array}{l}- \\
14.75 \\
7\end{array}$} & 28 & .000 \\
\hline & TEST & & & & & & & & \\
\hline
\end{tabular}


This statistical computation shows significant increase of students' writing ability since t-value which is higher than $t$-table with the significance level of less than $0.05(14.757>2.048)(0.000<0.05)$.

Table 2. The Improvement of Writing Aspects

\begin{tabular}{|c|c|c|c|}
\hline \multirow{2}{*}{ Writing Aspects } & \multicolumn{3}{|l|}{ Mean } \\
\hline & Pretest & Post Test & Gain \\
\hline Content & 17,75862 & 23,43103 & 0,47054 \\
\hline Organization & 15,46552 & 16,51724 & 0,220714 \\
\hline Vocabulary & 15,82759 & 16,44828 & 0,093774 \\
\hline Language Use & 20,22414 & 20,72414 & 0,110717 \\
\hline Mechanics & 3,103448 & 3,086207 & $-0,06322$ \\
\hline
\end{tabular}

\begin{tabular}{|l|l|l|l|l|l|}
\hline \multirow{2}{*}{$\begin{array}{l}\text { Aspects } \\
\text { Writing }\end{array}$} & Mean & Post Test & Gain & T-Value & Sig. \\
\cline { 2 - 5 } & Pretest & 23,43103 & 0,47054 & 16.794 & .000 \\
\hline Content & 17,75862 & 16,51724 & 0,220714 & 4.509 & .000 \\
\hline Organization & 15,46552 & 16,44828 & 0,093774 & 2.493 & .019 \\
\hline Vocabulary & 15,82759 & 20,72414 & 0,110717 & 2.342 & .027 \\
\hline Language Use & 20,22414 & 3,086207 & $-0,06322$ & .297 & .769 \\
\hline Mechanics & 3,103448 & 3,297 \\
\hline
\end{tabular}

The statistical computation above shows that the highest increase is content aspect. In addition, there is a statistically significant improvement of students' writing ability in the four aspects after they were taught using modified mind mapping, namely organization, vocabulary, and language use. It is revealed from t-values which are higher than $\mathrm{t}$-table with the significance levels of less than $0.05(16.794>2.048 ; 4.509>2.048$; $2.493>2.048 ; 2.342>2.048)(0.000<0.05)$. On the other hand, there is no statistically significant improvement of students' writing ability in mechanic after they were taught using modified mind mapping. It is revealed from tvalue which is lower than $t$-table with the significance level of more than $0.05(0.297<2.048)(0.769>0.05)$.

\section{Discussion}

The main purpose of this research was to investigate the effectiveness of the integration of (MM) and TSI in learning writing. There were two formulated research questions in this study. The first research question was formulated to find out whether there was a significant improvement of students writing ability after being taught by using modified mind mapping technique and the second question was to find out writing aspect which most significantly improved. Considering the result obtained from paired sample T-test analysis, it was found that there was a significant improvement of students writing ability. The most significant improvement score was in writing content. The organization also significantly improved after writing content but not as high as that one of content.

Modified mind mapping technique is effective to enhance the students' writing ability through solving their problem in generating and organizing ideas. This technique, infact, was purposed to create a sufficient teaching procedures which are able to solve the students' writing problem, especially in prewriting process. Besides, it was aimed to provide the solution for the students at intermediate level who have mastered sufficient vocabularies and grammar, but have problem in organizing and generating ideas for writing. Mind mapping was used as the note, graphic organizer, and controller of the students' ideas for writing. As concluded by Bukhari (2016) that the learners who were taught through Mind maps, improved cohesion and coherence; content paragraph structure and length in writing. However, when it is implemented individually, it is assumed less effective because the students only organize their own limited ideas. It doesn't provide the students another resource to find the ideas related to writing topics. The nature of this TSI is smilar to Think-Pair-Share (TPS) where the students think the answer to the teacher's questions, then the teachers pairs the students to discuss the answer and share ideas (Sharma, 2018). 
By intergrating mind mapping into Think-Share- Interviewe (TSI) in this study, the students have opportunity for sharing ideas each other in group when they note and organize the ideas through mind mapping. As suggested by Manktelow (2011:6) that group brainstorming can be very effective for bringing the full experience and creativity of all members of the group to bear on an issue. When individual group members get stuck with an idea, another member's creativity experience can take the idea to the next stage. Related to three-step-interview (TSI), Slavin (1985) states that it is an effective technique to encourage students to share their thinking, ask questions, and take notes. It means that it is very effective for group brainstorming. For example, when one member gets stuck, another or other fellow members could help him/her out (Manktelow (2011).

In addition, the concept of three-step-interview is similar to the concept of cooperative learning techniques developed by Kagan (2009), where the learners can create interactive and encourage students to participate fully in the class. During the integration of Mind mapping and TSI, the students also can de velop their cognitive skill, for example in structure. When they do interview, some of them also get input in vocabulary and structure spontaneously. Based on my informal interview to the whole class, they stated that they also got input in vocabulary. When they interview each other, they exchange their ideas and it makes them able to enlarge their ideas related to the topic being discussed. Besides that, they also get some input, especially in vocabulary. For example, when one student did not know how to say a certain vocabulay in English, he just mixed it into Indonesian language. In this time his peer helped him.

During the learning process, every student is eager to ask his peer, especially during the interview steps. Each of them tried to show his notes during the process of mind mapping (the third step, as it was mentioned before). In this step each student kept asking the idea related to the topic and it really helps them elaborate or develop their idea related to the topic given by the teacher. During this step actually each student get input from their friends, which is similar to peer corrective feedback (Sultana, 2009; Kamimura,2006 ; Zeng ( 2006); Based on emperical data in this study, it was found that learners creativity and motivation also happens. For example, they can enlarge their writing by combining the input they got during the interview.

As the pedagogical implications, this present research implies that the English teachers can integrate MM and TSI, especially to solve students' problem in prewriting process so that the students can develop the content of their writing, as it is the main problem of the learners (Richards and Renandya, 2002) . It is purposed to facilitate the students for practicing individual and group brainstorming at the same occasion. Moreover, it also remains that the modified of some technique concepts in teaching are essentially needed to maximize the teaching process since each tecnique and the situation of the learners are are different. Thus, learning objectives can optimally be achieved.

\section{Conclusion}

The integration of MM and TSI is effective in enhancing writing process, especially in developping the content aspect of writing. The students could enlarge their ideas as the result of interview. During the interviview, the students also could get new vocabulary related to the topic being discussed since the students expressed the unknown vocabulary using their own language and other (s) gave spontateous help. In other words they get input through their own output (Swain (1985) and Swain and Lapkin (1995). However this technique is more suitable for intermediate level, since the learning process do not focus much on language use aspect.

\section{References}

Akbar, RS and Hanan A. Taqi, HA (2017). Does mind mapping enhance learning? International Journal of English Language Teaching. Vol.5, No.8, pp.65-77, November 2017.

Aristy, I, Hadiansyah, R, and Apsari, Y. (2019). Using three step - interview to improve students' speaking ability.PROJECT. Volume 2, No. 2, March 2019 pp 74-79

Ary, Donald et al. (2010). Introduction to research in education. USA: Wadsworth Cenggage Learning.

Astrina, Marzeliaet.al. (2014). The use of clustering technique to improve students' skill in writing hortatory exposition text. e-Journal of English Language Teaching Society (ELTS): Vol. 2 No. 2, 2014.

Bailey, Stephen. (2006). Academic writing : A handbook for international student. New York: Routledge.

Brown, H. Douglas. (2001). Teaching by principles an interactive approach to language pedagogy. The United States of New York: Longman.

Bukhari, Syeda Saima Ferheen (2016). Mind mapping techniques to enhance efl writing skill. International Journal of Linguistics and Communication: June 2016, Vol. 4, No. 1, pp. 58-77.

Candraloka, Olyvia Revalita. (2016). Implementing three step interview in teaching speaking. Jurnal Edulingua: Vol 3. No. 1 Januari-Juni 2016. 
Ernidawati and Sutopo, D. (2017). Mind mapping and brainstorming strategies in students' interest. English Educational Journal. EEJ 7 (2) (2017) 164-168.

Fadillah, R. (2019). Students' perception on the use of mind mapping application software in Journal of Culture, English

Language Teaching, Literature \& Linguistics. ISSN: 2356-0401, E-ISSN: 2621-9158, VOL. 6, NO. 1, June 2019.

Fussalam, YE and and Renda Lestari, R. (2018). Improving speaking skill of the students of STKIP-MBthroughthe use of three-step interviewe technique. Getsempena English Education Journal (GEEJ) Vol.5 No.2 November 2018

Harmer, J. (2010).The practice of english language teaching. Pearson Longman.

Honsa, S.Jr. (2013). Self-assessment inefl writing: A study of intermediate efl students at a thai university. Voices in Asia Journal 2013,Vol.1Issue1.http://www.viajournal.org/admin/file_upload_name/pp._34-57.pdf.[Retrieved on

January 29, 2016]

Irawati, Rika. (2013).The effectiveness of three-step interview technique to teach speaking viewed from the students' language anxiety. Jurnal Eksos:November 2013, Th. IX, No. 3.

Jacobs, H.J. et al. (1981). Testing ESL composition: a practical approach. Rowley, MA: Newbury House. Chapter 2.

Kagan, Spencer. 2009. Kagan Cooperative Learning. San Clemente: Kagan Publishing. Chapter 1.

Kamimura, T. (2006). Effects of peer feedback on efl student writers at different levels of English proficiency: A japanese context tesl. Canada Journal, 23(2), 12-39. https://doi. org/10.18806/tesl.v23i2.53. [Retrieved online: February 2, 2019]

Luzzatto, Edda and Giordano DiMarco. (2010). Collaborative learning. methodology, types of interactions and techniques. New York: Nova Science Publishers, Inc. Chapter 5.

Manktelow, James C.E.O. (2011). Brainstorming toolkit. London: Mind Tools.

Marashi, Hamid and Homayra Khatami. (2017). Using cooperative learning to boost creativity and motivation in language learning. Journal of Language and Translation: Volume 7, Number 1(13) 43-58.

Orrange, Marry Beth. (1993). Promoting excellent teaching. The Annual International Conference for Community College Chairs, Deans, and Other Instructional Leaders: Phoenix, AZ,February 17-20.

Richards, Jack C. and Willy A. Renandya. (2002). Methodology in language teaching-An anthology of current practice. New York: Cambridge University Press.

Riswanto and Putra, Pebri Prandika. (2012).The use of mind mapping strategy in the teaching of writing at SMAN 3 Bengkulu, Indonesia. International Journal of Humanities and Social Science: Vol. 2 No. 21, November 2012.

Riswanto. (2016). Improving the students' ability in writing report genre through mind mapping at junior high schools in south sumatera, Indonesia. International Journal of Social Sciences: Volume 2 Issue 1, 2016.

Saputro AR, Basori, and Budiyanto, CW. (2017.) The application of mind mapping learning model to improve the students' learning outcomes and liveliness. Advances in Social Science, Education and Humanities Research (ASSEHR), volume 158International Conference on Teacher Training and Education 2017 (ICTTE 2017.

Sharma, L, H. (2018). TPS (Think-pair-share): An effective cooperative learning strategy for unleashing discussion in classroom interaction. USA: International Journal of Research in Social Sciences. Vol. 8 Issue 5(1).

Sultana, A. (2009). Peer correction in ESL classroom. BRAC University Journal, 6(1), 11-19. [Retrieved online on February 2, 2019]

Suyanto, A. (2015). The effectiveness of mind mapping in improving students' writing skill viewed from Their IQ. IJEE (Indonesian Journal of English Education), 2 (2), 2015, 101-119

Swain, M. (1985). Communicative competence: some Roles of Comprehensible input and Comprehensible Output in its Development. In Susan M. Gass and Carolyn G Madden, eds. Input in Second Langauge Acquisition, 235-253. Rowley, MA: Newbury House.

Swain, M. and S. Lapkin. (1995). Problems in output and the cognitive processes they generate: A step towards second language learning.' Applied Linguistics 16:371-391.

Triza, Retno et.al. (2016). The effect of clustering technique towards students' writing skill of narrative text in high school 5 Pariaman, West Sumatera. Research Journal of Social Sciences: 9(2), March 2016.

Wulandari, Silvia and Don Narius. (2017). Using three steps interview technique to improve speaking ability of senior high school students. Journal of English Language Teaching: Volume 6 No. 1 Serie A, March 2017.

Yuliasri, I. (2013). Applicability of cooperative learning techniques in different classroom contexts. Arab World English Journal. AWEJ June 2013. ELTL Indonesia Conference Proceedings 2012

Yunus, Melor and Chan Hua Chien. (2016).The use of mind mapping strategy in Malaysian university english test (MUET) writing. Creative Education: 7, April 2016, 619-626.

Zeng, Y. (2006). Peer feedback in college slw classroom. Sino-us English Teaching, 3(3), 23-35.[Retrieved online on February 2, 2006 